\title{
The Importance of Sectoral Differences in the Application of (Complementary) HRM Practices for Innovation Performance
}

\author{
Laursen, Keld
}

Document Version

Final published version

Publication date:

2001

License

CC BY-NC-ND

Citation for published version (APA):

Laursen, K. (2001). The Importance of Sectoral Differences in the Application of (Complementary) HRM

Practices for Innovation Performance. DRUID - Danish Research Unit for Industrial Dynamics. DRUID Working Paper No. 01-11

Link to publication in CBS Research Portal

\footnotetext{
General rights

Copyright and moral rights for the publications made accessible in the public portal are retained by the authors and/or other copyright owners and it is a condition of accessing publications that users recognise and abide by the legal requirements associated with these rights.

Take down policy

If you believe that this document breaches copyright please contact us (research.lib@cbs.dk) providing details, and we will remove access to the work immediately and investigate your claim.
}

Download date: 26. Apr. 2023 


\section{$\mathbf{D}_{\text {ANISH }} \mathbf{R}_{\text {ESEarch }} \mathbf{U}_{\text {NIT FoR }} \mathbf{I}_{\text {NDUSTRIILL }} \mathbf{D}_{\text {YNamics }}$}

DRUID Working Paper No 01-11

The Importance of Sectoral Differences in the Application of (Complementary) HRM Practices for Innovation Performance

By

Keld Laursen

July, 2001 


\title{
The Importance of Sectoral Differences in the Application of (Complementary) HRM Practices for Innovation Performance
}

\author{
Keld Laursen \\ Department of Industrial Economics and Strategy \\ Copenhagen Business School, Howitzvej 60, 2000 Frederiksberg, Denmark \\ and Centre for Economic and Business Research, Danish Ministry for Trade and Industry, \\ Langelinie Allé 17, 2100 Copenhagen Ø, Denmark \\ Voice: + 45 38152565, Fax: + 4538152540 \\ mailto:kl.ivs@cbs.dk, http://www.cbs.dk/departments/ivs/laursen/
}

Second draft, April 11th., 2001

\begin{abstract}
Recent theoretical and empirical analysis in the field of economic organisation has focussed almost exclusively on identifying organisational practices and complementarities between such practices, invariant to the type of activity in question. However, this paper takes its point of departure in the observation from organisational theory that more knowledge-intensive production activities often involve higher degrees of strategic uncertainty for firms and performance ambiguity in relation to individual employees. Therefore, the "organic" or "clan" form of organisation - involving the application of "new" HRM practices - is expected to yield a higher outcome in terms of performance within knowledge-intensive sectors of the economy, as compared to other sectors. Moreover, knowledge-intensive activities are likely to require the utilisation of local knowledge to a higher degree than less knowledge-intensive activities. Given that the application of new HRM practices is one way of supporting such local knowledge, it should also for this reason be expected that the application of HRM practices are more effective for knowledge-intensive production activities. A sample of 726 Danish firms with more than 50 employees in manufacturing and private services is applied. The results show that HRM practices are more effective in influencing innovation performance when applied together, rather than when applied alone. In other words, organisational complementarities obtain. Moreover, it is shown that the application of (complementary) HRM practices is more effective in what is normally perceived to be more knowledge-intensive sectors as compared to less knowledge-intensive sectors.
\end{abstract}

Keywords: human resource management practices, organisational complementarities, innovation performance

JEL: C21, D21, D23

ISBN(87-7873-110-0

Acknowledgements: This research was undertaken within the LINK programme at the Copenhagen Business School. I would like to thank Nicolai Foss, Anna Grandori, Volker Mahnke and the participants in the R\&D Management Conference held in Wellington, New Zealand, February 2001, for comments made on an earlier version of this paper. I also wish to thank the participants in the DISKO project for allowing me to use the data applied. In particular, I wish to thank the persons responsible for carrying out the survey, including project leader Bengt-Åke Lundvall, Allan Næs Gjerding, Kenneth Jørgensen, Frank Skov Kristensen, Reinhard Lund, Poul Thøis Madsen, Peter Nielsen and Søren Nymark. The usual disclaimer applies. 


\section{Introduction}

This paper is concerned with the impact of complementary human resource management (HRM) practices on innovation performance. Given the close connection between knowledge possessed by the personnel of the firm and the products and services obtainable from the firm (Penrose, 1959), it is uncontroversial that a firm's ability to produce new products and other aspects of performance are inextricably linked to how it organises its human resources. Nevertheless, despite the widely held belief in the importance of managing knowledge and learning through human resource practices, their performance implications remain assumed rather than empirically corroborated. First, while recent research suggests that consistency among practices matters for firm-level performance, supporting evidence is sparse, and in many cases limited to particular industries (e.g., Ichniowski et al., 1997; Mendelson and Pillai, 1999). Second, with a few exceptions (e.g., Huselid, 1995; Ichniowski et al., 1997), the effect of HRM practices has been examined on an individual work practice basis. However, if Edgeworth complementarities (i.e. doing more of one thing increases the returns of doing [more of] other things) obtain, the effectiveness of HRM practices will be greater, when applied in systems rather than alone. Therefore, such complementarity effects should be considered in the analysis. Third, theoretical analysis has focussed almost exclusively on identifying organisational practices and complementarities between such practices, invariant to the type of activity in question (e.g., Milgrom and Roberts, 1995). Finally, the assumption of sectoral invariance also applies to a number of empirical studies (e.g., Huselid, 1995; Michie and Sheehan, 1999; Laursen and Foss, 2000). Yet, while it might be obvious that, for example, an electronics firm will benefit from the application of formal HRM practices, it is not equally obvious that a smaller construction firm will gain (equally) from applying such practices. Hence, the empirical research of this paper is devoted to the more detailed unfolding of sectoral regularities in the effect of HRM practice complementarities on innovation performance, across an entire economy.

An empirical model of firm's ability to innovate is estimated, using data from a Danish survey of 1900 business firms (in manufacturing and services) conducted in 1996. The survey aimed at tracing the relationship between technical and organisational innovation. The survey 
data have subsequently been linked to Statistics Denmark's register data. In the attempt to estimate the effect of the application of HRM practices — and complementarities among them - firm size and linkages to users or suppliers are controlled for. The effect of three HRM variables ("team work", "delegation of decision rights" and "performance related pay") both individually ("the direct HRM effect") and when applied in systems ("the HRM complementarity effect") is examined. Given the expectation with respect to important differences in the effect of the HRM practices on performance, the model is estimated while allowing for varying parameters at the level of nine broad sectoral categories of firms.

The paper is structured as follows. First, the theoretical link between the application of HRM practices and innovation performance is discussed (Section 2). Second, an empirical model is proposed and subsequently tested (Section 3 ). Section 4 concludes and draws some implications for future theoretical and empirical work.

\section{Theoretical considerations}

"New HRM practices" is the overall label put on a host of contemporary changes in the organisation of the employment relation, referring to team-based organisation, continuous (often team-based) learning, decentralisation of decision rights and incentives, emphasis on internal knowledge dissemination, etc. While there may be strong financial performance effects, productivity effects and flexibility advantages of such new HRM practices (Huselid, 1995; Ichniowski et al., 1997; Mendelson and Pillai, 1999), the main emphasis of this paper is on the impact on innovation performance, in particular, on product innovation. ${ }^{1}$ This section will first lay out, in general terms, some of the links between the application of new HRM practices and innovation performance (Sub-section 2.1). Second, it will be argued that such practices are more effective with respect to performance, when implemented in knowledge-intensive firms (Subsection 2.2).

1 For an in-depth discussion of innovation performance vis-á-vis other measures of performance, see Laursen and Foss (2000) 


\subsection{The role of new HRM practices for innovation}

New HRM practices can be conducive to innovative activity for at least three types of reasons: (a) the application of HRM practices may increase the level of decentralisation, and such an environment may better allow for the discovery and utilisation of local knowledge in the organisation; (b) team practices, involving job-rotation are likely to provide coordination advantages in the sense that engineers (or "workers") perform several tasks and therefore understand the technological problems of colleagues better; and (c) teams often bring together knowledge and skills which - prior to then introduction of teams - existed separately, potentially resulting in incremental process and product improvements.

With regard to point (a), one notable feature of many new HRM practices is that they increase decentralisation process with respect to innovations/improvements, in the sense that problem-solving rights are delegated to the shopfloor. Accomplished in the right way, this amounts to delegating rights in such a way that they are co-located with the pertinent knowledge, much of which is inherently tacit. In other words, increased delegation may better allow for the discovery and utilisation of local knowledge in the organisation, particularly when there are incentives in place that foster such discovery (Hayek, 1948; Jensen and Meckling, 1992). Relatedly, the increased use of teams that is an important component in the package of new HRM practices also means that better use can be made of local knowledge, leading to improvements in processes and perhaps also to minor product improvements. Indeed, it is exactly for those reasons that Itoh (1994b) argues that the existence of Japanese incremental and continuous process innovations depend on the co-location of the relevant problems with the appropriate decision rights, at the team level, combined with appropriate pecuniary (typically in the form of performance-pay at the supra-individual level) and non-pecuniary incentives (typically in the form of long-term employment contracts and promotion schemes). Nevertheless, it should be pointed out that the inherent incentive-problem in introducing teams (that is, inputs, outputs and behaviour are not easily gauged and fairly rewarded) is somewhat mitigated since team-work involving job-rotation (within the team), is likely to facilitate monitoring and sanctioning among the members (Itoh, 1993). 
As stated in point (b) above, if team-work/research involves that the participants perform more than one task, then coordination between the tasks is likely to be easier. Because the agents work jointly on all tasks, they will be able — at least to some degree — to share knowledge and information and to adjust their activities without a central unit (Itoh, 1994a). Then, if lateral communication (for example between engineers) has some advantages over centralised, vertical coordination, such a team-based organisational set-up will be superior. If engineers, for example, tend to have better information about their (local) tasks, lateral communication may have an advantage in utilising such information, provided that communication is costly (Bolton and Farrell, 1990). It should be pointed out, however, that this coordination effect is to be measured against the negative effect due to the loss of specialisation gains from each individual task.

With respect to point (c), teams can do something more than to support local knowledge and to enhance coordination between tasks, since they are often composed of different human resource inputs. In other words, teams often bring together knowledge that hitherto existed separately, potentially resulting in non-trivial process improvements (when teams are on the shop floor) or "new combinations" that lead to novel products (Schumpeter, 1912/1934)(when teams are used in product development departments). Generally, increased knowledge diffusion, for example, through job rotation, and increased information dissemination, for example, through IT, may also be expected to provide a positive contribution to the firm's innovation performance, for obvious reasons. In the context of product development, Aoki (1990) suggests that the use of team-work involving job-rotation, increases the interaction between the different key actors in various successive stages (basic conceptualisation, successive phases of detailed design, prototype fabrication, testing, redesign, mass production, and marketing) of product development. Since processes of product development are characterised by various feedback loops between the "phases" (Kline and Rosenberg, 1986), job-rotation among different engineering offices, as well as between engineering jobs and supervisory jobs at the factory, facilitates the knowledge sharing needed for horizontal coordination among the different phases of development.

Thus, there are reasons to expect that the adoption of new HRM practices leads to increased innovation performance. Arguably, the adoption of a single such practice may provide a contribution to innovative performance. For example, rewarding shop floor employees for minor process improvements is likely to increase such incremental innovation activity, more or less 
regardless of the specific firm in which the reward system is implemented. However, other practices may not be expected to have significant impact on innovation performance, if implemented in isolation. At least to the extent that implementing new HRM practices is associated with extra effort or with disutility of changing to new routines, etc., employees will have to be somehow compensated. Thus, we would expect many new HRM practices to work well (in terms of both profits and innovation performance) only if accompanied with new, typically more incentive-based, remuneration schemes. In general and on a priori grounds, new HRM practices should be expected to be most conducive to innovation performance when adopted, not in isolation, but as a system of mutually reinforcing practices. The complementary nature of many of the elements of (formal and informal) organisational structure has been examined in an emerging important literature in organisational economics (notably Milgrom and Roberts, 1990; Aoki and Dore, 1994; Milgrom and Roberts, 1995; Holmström and Roberts, 1998). The arguments in favour of this are relatively straightforward. For example, the application of team-based HRM practices such as interdisciplinary workgroups and quality circles, without at the same time allocating the appropriate decision rights down to the team level, is not likely to be effective in influencing performance (Cohen and Bailey, 1995; Lawler et al., 1995). Moreover, all such practices are likely to be complements to various incentive-based remuneration schemes (in particular when based on team or firm performance), profit sharing arrangements, and promotion schemes (Zenger and Hesterly, 1997).

\subsection{Sectoral differences in the effectiveness of new HRM practices}

While the previous section pointed to the general observation that (complementary) HRM practices are likely to enhance innovative activity, it not reasonable to believe that such practices are equally effective in their application, across different sectors of economic activity. In this respect, we know from the literature on the economics of technological innovation that the mode (according to the dominant source of knowledge input) and level (in terms of the innovation frequency) of innovation tend to follow broad sectoral regularities, in the sense that "typical" firms can be identified for broader categories of economic activity (Pavitt, 1984). Although it is intuitively appealing that different economic activities should be governed in different ways, it 
is not obvious in which ways such (different) activities should be governed in terms of the organisational structure and related HRM practices. However, the so-called contingency theories from the organisational literature can be of assistance, as a starting point for bridging this gap. One such contingency approach has been advanced by Paul Lawrence and his colleagues (see e.g., Lawrence, 1981), within the the Harvard Programme. In this work, the organisational form emerges as a function of two variables, namely resource scarcity ("resource tensions") on the one hand, and strategic uncertainty on the other hand. In this context strategic uncertainty refers to the number of different types of competitors the firm has to face and to the stability or turbulence of the sources of knowledge, including suppliers, universities and government research etc. In contrast, resource tensions refer to the fact that organisations require (scarce) resources in terms of raw material, physical and human capital, and favourable resource exchanges.

In this framework different organisational forms emerge as an adaptation to these two types of pressure from the external environment. In other words, depending on whether resource tensions and strategic uncertainties are relatively high or low respectively, certain types of organisations emerge as the "best fit" for each combination (in a $2 \times 2$ matrix). If , for instance, strategic uncertainty is low but resource tensions are high, the best fit organisational form is supposed to be an organisational type which can be labelled a "machine bureaucracy". Firms of this type produce goods in an environment, where price factors play a major role. Hence, the best fit organisation is a highly formal and centralised form that requires a low degree of integration because it is oriented toward high productivity and cost cutting (Grandori, 1987). Other the other hand, if firms are active in knowledge-intensive industries ${ }^{2}$ they will typically face a situation in which resource tensions are medium, while strategic uncertainty is high, due a high rate of technological change (Lawrence, 1981, pp. 328-329). In this situation the best fit organisational arrangement can be characterised as being an "organic form" (Burns and Stalker, 1961), that is a flexible, decentralised, informal and highly integrated organisational structure. The organic form is supposed to be the best fit organisation, under these circumstances, since the reaction speed with respect to changes in the external environment ("flexibility") is likely to be higher for firms applying the organic form of organisations as compared to bureaucratic forms.

2 Knowledge-intensive industries are in this paper taken to be those industries in which firms typically have a strong internal capacity to develop new products or services. For an operationalisation of knowledge-intensities in the context of the Pavitt taxonomy, see Section 3.1. 
Another contingency approach, yielding similar predictions, has been advanced by William Ouchi (e.g., 1980). Ouchi takes as his starting point that the transactions cost approach identifies the conditions which give rise to the cost of exchanges between individuals, namely goal incongruence and performance ambiguity. Performance ambiguity has to do with how easily inputs and outputs of the production process are measured. If inputs and outputs are not easily measured - for instance if both factors of production as well as outputs are intangible performance ambiguity will be high. Goal incongruence refers to the fact that individuals (members of the organisation) have only partly overlapping goals in many cases. Hence in these cases, when left on their own, the individuals would pursue incongruent objectives and their efforts would be uncoordinated. However, Ouchi $(1979 ; 1980)$ argues that - when a group within a firm has been socialised in a certain way - goal congruence can in fact be high.

Different sizes of parameters with respect to the two variables then helps in distinguishing three basic mechanisms of control as the efficient response to economic coordination, namely markets, bureaucracies, and clans. Markets are seen to be the efficient form of organisation, when performance ambiguity is low and goal incongruence is high, while bureaucracies are argued to be the efficient form when both goal incongruence as well as performance ambiguity are moderately high. Moreover, a bureaucracy typically relies on the standardisation of inputs, processes, jobs and behaviour, so that output can be approximated. But when performance ambiguity reaches very high levels - performance control becomes impossible. In such a situation clans are seen to be the most efficient form of organisation, given that goal incongruence can be considered to be low, due to a particular socialisation process. Firms applying these organisations are typically active in technologically advanced or closely integrated industries (Ouchi, 1980, p. 136), where teamwork is common and where technological change often leave individual performance highly ambiguous. In this situation a bureaucracy will often fail, making the clan — relying on goal congruence - the only form of mediation. Hence, the predictions for what concern knowledge-intensive firms, resemble the predictions of the Lawrence. Therefore, given the attributes of the "organic" or "clan" type of organisation (the flexible, decentralised, informal and highly integrated organisational structure), work practices associated with this organisational structure (the HRM practices reflecting team production and delegation of responsibility in particular) should suit firms in knowledge-intensive industries better, and hence a higher output in terms of new product development (innovations) from the 
application of these practices should be expected.

In addition to the effects identified by the contingency approaches, in terms of flexibility of organisations in adapting to changes in the external environment and in terms of goal congruence within firms, effects relating more directly to the knowledge-creation process might also be of importance in the context of sectoral differences. One such effect has to do with the observation that organic forms (associated with new HRM practices) can better assist in creating and utilising local knowledge (as discussed in the Sub-section 2.1 above). Since the importance of local (specific) knowledge is likely to be greater when production processes are more complex and knowledge-intensive, the effect of increased discovery and utilisation of knowledge in the organisation - by means of "releasing" local knowledge using team-based HRM practices (involving increased delegation) — is likely to be stronger for firms affiliated to knowledgeintensive industries.

The standard principal-agent (P-A) literature suggests that pay-for-performance should be avoided in situations of high uncertainty, since efforts (inputs) from the agents cannot be measured easily under these circumstances (Holmström, 1979). Given the level of uncertainty and given that efforts of agents are not easily gauged, the problem for the agent considered in P-A theory, is that she is not able to assess whether she will be fairly rewarded, since she is not able control the (highly) uncertain environment. In order to accept the pay-for-performance arrangement, she will have to be compensated for the risk by the principal. Since more risk is transferred to the agent than is necessary (the agent is assumed to be risk-adverse), under conditions entailing greater levels of uncertainty, the use of pay-for-performance is not considered to be efficient within P-A theory in such situations. However, according to Prendergast (2000) this prediction is not supported by the available empirical evidence, since many studies exhibit a positive correspondence between measures of uncertainty and the use of pay-for-performance (output-based pay). Against this background, Prendergast infers that when agents work in more uncertain situations, the agents will know more than the principals about what the agents should be spending their time on. Therefore, given the information asymmetry and given that output can be measured, it is preferable to delegate responsibility to agents but, to constraint their discretion, to base compensation on observed output. ${ }^{3}$ The reason is that an

3 It should be pointed out that when team-work is applied, individual contributions to output are often not easily be identified, and compensation must therefore be based on team performance, 
output-based employment contract is the only way to monitor the agents' efforts, although it implies higher wage-costs. Hence, if knowledge-intensive activities are indeed more uncertain, as compared to other economic activities, we should expect the delegation of responsibility (for instance to teams) to be more effective in knowledge-intensive activities.

In sum, theory would lead us to expect that (i) because of complementarities between new HRM practices, systems of HRM practices will be significantly more conducive to innovation than individual practices. Moreover, (ii) the more knowledge-intensive production processes we are dealing with, the stronger is the impact on innovation performance from applying (complementary) HRM practices expected to be. In the following, these ideas are empirically examined.

\section{Empirical analysis}

\subsection{The empirical model}

Based on the arguments put in the section above, the empirical model can be specified as follows:

$$
a=f\left(\beta_{1} z, \beta_{2} x\right)
$$

where $a$ is the ability to produce innovations, $\beta_{1}$ and $\beta_{2}$ are parameter vectors, and $z$ is a set of (exogenous) determinants of innovation, related to the application of human resource management practices, while $x$ is a set of other variables explaining innovative performance across business firms. The variables included in the vector $\mathrm{x}$, are arguably to be standard variables in explaining innovation performance (Geroski, 1990; Kleinknecht, 1996). This model can be made operational in the following way:

rather than on individual performance. Under such circumstances a number of free-riding problems within the teams arise, especially when workers vary in their ability (Prendergast, 1999). I abstain from discussing this issue further in this paper, but for a good discussion of the topic, see Prendergast (1999, pp. 39-44). 


$$
A_{i}=\alpha_{s} S E C T_{i}+\delta_{s} S I Z E_{i}+\psi_{s} \operatorname{LINK}_{i}+\eta_{s} H R M P_{i}^{j}+\ldots+\eta_{s} H R M P_{i}^{n}+\varepsilon_{i}
$$

where $A_{i}$ expresses the firms' ability to innovate. If the firm in question is a non-innovator, the variable takes the value of 0 , if the firm has introduced (in the period 1993-95) a product or service, new to the firm the value is 1 , if the firm has introduced a product that is new in a Danish context over the period, the value is 2 , while the value for this variable is 3 if the firm has introduced a product (or service) which is new to the world. Hence, only the final category qualifies for being an innovation in the strict sense of the word. $S$ indicates that the parameter is allowed to vary according to which sector each firm belongs. The sample includes 253 non-innovators, 333 firms that produced products/services that were new only to the firm itself, 73 firms that produced products/services that were new to the national market, while 67 firms introduced products/services that were new to the world.

For what concerns the sectoral classification, the Pavitt taxonomy (1984) is applied for the four sectors consisting of manufacturing firms. For the service firms in the sample, five additional sectors are constructed. Explanations and details of the sectoral classification applied may be found in Appendices 1 and 2 to this paper. The sectoral classification of the firms in the sample is key to this paper, since this classification is used to gauge whether or not knowledgeintensive firms get more innovative activity out of applying new (complementary) HRM practices. In this "augmented" Pavitt taxonomy, firm types with the strongest internal capacity to develop new products and services are specialised supplier firms, science based firms and ICT (Information and Communication Technology) intensive service firms. Consequently, these firm types are considered to have the highest knowledge-intensity. Firm types with the lowest capacity to develop new products and services internally are craft firms, specialised traditional service firms, scale-intensive service firms, and to some extent supplier dominated (manufacturing) firms. Scale-intensive firms and wholesale trade firms may be considered to be intermediate in relation to knowledge intensity (see Laursen and Foss, 2000, p. 12).

As is common in studies aiming at explaining innovative performance (e.g. Geroski, 1990; Michie and Sheehan, 1999) firm size (SIZE) is controlled for. Another control variable includes whether or not the firm in question has increased its vertical interaction with other firms, being 
it either upstream or downstream $(L I N K)$. This variable is supposed to pick up the effect of interactions with suppliers and users for innovation performance as stressed by, for example, von Hippel (1988). Since the model is estimated, while allowing the parameters to differ according to sectoral affiliation, the intercepts (SECT) should be allowed to vary for each of the nine sectors in the analysis.

The variables $H R M P_{i}{ }^{j} \ldots H R M P_{i}^{n}$ are the new HRM variables, that is, those variables which are key to the analysis. Six binary variables pertaining to new HRM practices, which express whether or not firms apply "interdisciplinary workgroups", "quality circles", "planned job rotation", "integration of functions", "delegation of responsibility", and finally, "performance related pay" are applied. These variables are then "clustered" into groups of practices so that we get three different variables, each reflecting the application of team work (TEAM), performance related pay (PPAY) and delegation of decision rights (DRESP). The variable TEAM is made up by four underlying (binary) HRM variables, namely "interdisciplinary workgroups", "quality circles", "planned job rotation", and "integration of functions". Hence, it will take the value of zero, if a given firm applies none of the four underlying practices, while it will take the value of four if all four team work practices are applied. DRESP will take the value of one, if the firm responds that it delegates responsibility, and at the same time responds that the individual employee plans her own work on a daily basis. Else the value of this variable will be zero. For what concerns the PPAY variable it simply takes then value of one if the firm has responded that it uses such practices, otherwise zero .

However, as argued earlier, work on complementarities suggests that HRM practices are more effective when they are applied in systems relative to when they are applied alone. Hence, models are constructed in which HRM practices enter the equation, to be estimated, in certain configurations or systems:

$$
A_{i}=\alpha_{s} S E C T_{i}+\delta_{s} S I Z E_{i}+\psi_{s} L I N K_{i}+\eta_{s} H R M S_{i}+\varepsilon_{i}
$$

where the notation is the same as in Equation (3). $H R M S_{i}$ denote a HRM system, made up by as the sum of the three HRM practices. Subsequently, the estimations made shall be compared, when applying the HRMPs individually, and when they appear in a HRM system.

Concerning the signs of the parameters for each variable all signs are expected to be positive, 
except for what concerns size, where larger firms are expected to be more likely to innovate (negative sign).

\subsection{The data}

The main source of data for this paper is the DISKO database. The database is based on a questionnaire which aims at tracing the relationship between technical and organisational innovation in a way that permits an analysis of new principles for work organisation and their implications for the use and development of the employee's qualifications in firms in the Danish private business sector. The survey was carried out by the DISKO project at Aalborg University in 1996. The questionnaire was submitted to a national sample of 4,000 firms selected among manufacturing firms with at least 20 full-time employees and non-manufacturing firms with at least 10 full-time employees. Furthermore, all Danish firms with at least 100 employees were included in the sample, i.e. a total of 913 firms. The resulting numbers of respondents were 684 manufacturing and 1,216 non-manufacturing firms, corresponding to response rates of 52 per cent and 45 per cent, respectively. The first descriptive analysis of the survey can be found in Gjerding (1997). The database is held by Statistics Denmark, and the data on the firms in the database, can be linked to regular register data, also held by Statistics Denmark. In the case of this paper data have been obtained on the size of the firms in the sample from regular register data. In this paper the choice was made to work only with firms with more than 50 employees, since we are dealing with the application of formal HRM practices — practices which are simply less meaningful for smaller companies (why use team-work HRM practices, if the firm is not larger than a typical team?). By retaining only firms in the sample larger than 50 employees we end up with a total of 726 firms.

Table 1 displays descriptive statistics for the explanatory variables. It can be seen from the table that the majority of the firms in the sub-sample of larger firms (with > 50 employees) are manufacturing firms (480 firms), while the service firms make up only 246 firms of the total DISKO sub-sample. 4.4 per cent apply no new HRM practices at all, while 13.9 percent apply all six work practices, used in the analysis. About half of the firms use delegation of responsibility (56.7 per cent), while just about the same is the case for the application of 
Table 1: Descriptive statistics for a set of DISKO variables $(n=726)$

\begin{tabular}{lrr}
\hline \hline Variables & Number of firms & \% of sample \\
\hline Scale-intensive & 190 & 26.2 \\
Supplier dominated & 133 & 18.3 \\
Science based & 57 & 7.9 \\
Specialised suppliers & 100 & 13.8 \\
Crafts & 41 & 5.6 \\
Wholesale trade & 90 & 12.4 \\
Specialised traditional services & 48 & 6.6 \\
Scale-intensive services & 27 & 3.7 \\
ICT-intensive services & 40 & 5.5 \\
No HRM practices & 32 & 4.4 \\
One HRM practice & 56 & 7.7 \\
Two HRM practices & 105 & 14.5 \\
Three HRM practices & 156 & 21.5 \\
Four HRM practices & 156 & 21.5 \\
Five HRM practices & 120 & 16.5 \\
Six HRM practices & 101 & 13.9 \\
\hline No TEAM practices & 52 & 7.2 \\
One TEAM practice & 119 & 16.4 \\
Two TEAM practices & 184 & 25.3 \\
Three TEAM practices & 183 & 25.2 \\
Four TEAM practices & 188 & 25.9 \\
\hline Delegation of responsibility (binary) & 412 & 56.7 \\
\hline Performance related pay (binary) & 364 & 50.1 \\
\hline 51-100 employees & 223 & 30.7 \\
101-200 employees & 261 & 36.0 \\
200+ employees & 242 & 33.3 \\
\hline \hline
\end{tabular}

performance related pay (50.1 per cent).

\subsection{Estimation}

Since the dependent variable is a discrete variable, an ordered probit model is applied as the means of estimation. Hence, the method is maximum likelihood estimation (MLE), which provides a means of choosing an asymptotically efficient estimator for a set of parameters (for an exposition of the properties of ML estimators, see Greene, 1997, p. 129). 
Table 2: Probit estimation with sector-specific slopes, explaining innovative performance across 726 Danish firms - six HRM practices combined

\begin{tabular}{|c|c|c|c|c|c|}
\hline \multirow[b]{2}{*}{ Variable } & & \multicolumn{2}{|c|}{ Model (i) } & \multicolumn{2}{|c|}{ Model (ii) } \\
\hline & & Estimate & $p$-value & Etimate & $p$-value \\
\hline \multicolumn{2}{|c|}{ INTERCEPT } & -1.724 & 0.000 & -2.249 & 0.000 \\
\hline \multirow[t]{9}{*}{ HRMS } & Scale-intensive & 0.105 & 0.001 & 0.128 & 0.010 \\
\hline & Supplier dominated & 0.091 & 0,008 & -0.009 & 0.874 \\
\hline & Science based & 0.134 & 0.001 & 0.090 & 0.282 \\
\hline & Specialised suppliers & 0.169 & 0.000 & 0.129 & 0.027 \\
\hline & Crafts & -0.097 & 0.087 & 0.069 & 0.525 \\
\hline & Wholesale trade & 0.112 & 0.004 & 0.155 & 0.028 \\
\hline & Specialised traditional services & 0.010 & 0.853 & 0.043 & 0.668 \\
\hline & Scale-intensive services & 0.013 & 0.857 & 0.077 & 0.574 \\
\hline & ICT-intensive services & 0.128 & 0.010 & -0.141 & 0.221 \\
\hline \multirow[t]{9}{*}{ LINK } & Scale-intensive & & & 0.432 & 0.065 \\
\hline & Supplier dominated & & & 0.993 & 0.000 \\
\hline & Science based & & & 0.720 & 0.082 \\
\hline & Specialised suppliers & & & 0.740 & 0.007 \\
\hline & Crafts & & & -0.225 & 0.623 \\
\hline & Wholesale trade & & & 0.338 & 0.270 \\
\hline & Specialised services & & & 0.393 & 0.320 \\
\hline & Scale-intensive services & & & 0.288 & 0.564 \\
\hline & ICT-intensive services & & & 1.794 & 0.000 \\
\hline
\end{tabular}

Note: Insignificant sector-specific intercepts not included.

The results of the estimation of Equation (3) are reported in Table 2. I should be noted that the nine different intercepts from Equation (3) have been dropped since they were not individually significant. Hence, a common intercept has been assumed.

The size variable from Equation (3) has been dropped as well, since this variable turns out to be insignificant. This finding contrasts to the finding of Laursen and Foss (2000), where the size variable was found to be significant in a model using the entire DISKO sample, while using a fixed effects specification (as opposed to this paper, where the parameters are allowed to differ for each of the nine sectors). Given that the size variable turns out to be insignificant (except for a few cases in which the variable is significant [negative sign, 10 per cent level] for craft firms), it was dropped as a control variable. This finding can be taken as an indication of two factors. First, when only looking at firms larger than 50 employees the effect is less outspoken. Second, when the model is estimated within-sector, some additional variance explained by the size 
variable is removed. In other words, the average size of firms between the nine sectors differ markedly (since size is one of the criteria behind the taxonomy, this was to be expected), but the effect of variance in size is not particularly important within each sector.

The results also confirm that firms' external linkages are important to innovation, since the parameters for vertical linkages (LINK) are significantly different from zero in the case of all four manufacturing sectors, as well as for ICT-intensive service firms (for which the variable is particularly important, given the high parameter for this variable). This finding is in line with the predictions of von Hippel (1988) and as well as with the empirical findings of Rothwell et al. (1974) and Malerba (1992).

Nevertheless, the HRMS variable is the variable of main interest for the chief hypotheses of this paper. First it can be noted that Table 3 contains the estimations of Equation (2). ${ }^{4}$ That is, the estimation of the effects of the three individual HRM practices ("the direct HRM effect"). From this table it can be seen that delegation of responsibility (DRESP) is never significant, when viewed in isolation. Performance related pay (PPAY) turns out to be significant only for science-based and for craft firms. In this context it is particularly interesting to note that performance related pay appears to be related to innovation performance for science-based firms. Since these firms are operating in an environment associated with high levels of (uncertain) technological change, standard P-A theory does not anticipate such a relationship. Hence, the finding is more in line with the P-A model due to Prendergast (2000)(discussed in Sub-section 2.2), rather with the standard P-A model. For what concerns "team production" (TEAM), it may be seen that this variable has a significant and positive effect for what pertains to scale-intensive, specialised supplier, and to ICT-intensive service firms. Hence, overall it may be concluded that the application of new HRM practices is somewhat conducive to innovation performance. Nevertheless, the results from Table 3 can be compared to the estimations of HRMS in Table 2 ("the HRM complementarity effect"), where HRMS is made up by as the sum of three HRM practices reported in Table 3. From Table 2 [model (i)] it can be seen that "the HRM complementarity effect" has a positive and significant impact for six out of nine sectors in the

4 The full estimation of Equation (2), including all controls can be obtained from the author upon request. However, given that multicollinearity is a problem in a number of cases, the results are presented without the controls. At the same time it should be noted that this fact reenforces the point (this point will be elaborated upon below) that the new HRM practices are stronger when applied together as compared to when applied in isolation. 
Table 3: Probit estimation with sector-specific slopes, explaining innovative performance across 726 Danish firms - three types of HRM practices

\begin{tabular}{llrr}
\hline \hline & & Estimate & \multicolumn{2}{c}{$p$-value } \\
\hline INTERCEPT & & -1.731 & 0.000 \\
PPAY & 0.203 & 0.214 \\
& Scale intensive & 0.253 & 0.219 \\
& Supplier dominated & 0.778 & 0.011 \\
& Science based & 0.282 & 0.235 \\
& Specialised suppliers & 0.917 & 0.021 \\
& Crafts & 0.292 & 0.207 \\
& Wholesale trade & -0.012 & 0.970 \\
& Specialised traditional services & 0.170 & 0.708 \\
& Scale intensive services & 0.566 & 0.123 \\
\hline ICT intensive services & 0.008 & 0.960 \\
& Scale intensive & -0.066 & 0.745 \\
& Supplier dominated & -0.136 & 0.726 \\
Science based & 0.268 & 0.244 \\
Specialised suppliers & -0.205 & 0.626 \\
& Crafts & 0.230 & 0.289 \\
& Wholesale trade & -0.502 & 0.130 \\
Specialised traditional services & -0.146 & 0.741 \\
& Scale intensive services & -0.460 & 0.211 \\
\hline \hline ICT intensive services & 0.103 & 0.072 \\
& Scale intensive & 0.089 & 0.160 \\
& Supplier dominated & 0.065 & 0.575 \\
Science based & 0.122 & 0.096 \\
Specialised suppliers & -0.324 & 0.022 \\
& Crafts & 0.034 & 0.675 \\
Wholesale trade & 0.121 & 0.262 \\
Specialised traditional services & 0.000 & 0.999 \\
Scale intensive services & 0.223 & 0.046 \\
\hline ICT intensive services & &
\end{tabular}

Note: Insignificant sector-specific intercepts not included.

analysis, if the linkage control is excluded. The ranking of the effect according to the size of the HRMP parameters is as follows: (1) specialised suppliers, (2) science based, (3) ICT-intensive services, (4) wholesale trade, (5) scale-intensive, (6) supplier dominated. For what regards scaleintensive services (7) and specialised traditional services (8) the parameters are not significant, while the parameter has a negative sign with respect to craft firms (9). This ranking corresponds rather well (fits the ranking suggested in Section 3.1) to the expectation with respect to the effectiveness of HRM practices on innovation performance: the more knowledge-intensive 
production processes, the higher is the effectiveness of (complementary) HRM practices. However, if the linkage control is applied [model (ii)], the result still stands, but it is much less clear-cut. In particular, the parameters for science based and for ICT-intensive services firms become insignificant. However, it should be noted that there is a strong degree of multicollinearity between the measure of vertical linkages and the application of HRM practice systems in the case of ICT-intensive service firms.

\section{Conclusions and discussion}

This paper began by observing a number of stylised facts pertaining to the ongoing changes in the nature of the employment relation — often conceptualised in the term, "new HRM practices" - to the apparently systemic nature of these practices, and to their adoption by innovative firms. In particular, it was argued that while the adoption of individual HRM practices may be expected to positively influence innovation performance, an adoption of a package of complementary HRM practices could be expected to impact on innovation performance to a much higher degree. Moreover, it was argued that the more knowledge-intensive production processes we are dealing with, the higher will be the expected impact from applying HRM practices on innovation performance.

The results from the empirical analysis showed that in the current setting — when looking at firms with more than 50 employees and when allowing the parameters to differ according to nine broad categories of firms - firm size had no effect on the propensity to innovate across the sample. However, the variable measuring the strength of vertical linkages to other firms proved to be conducive to innovation in all four manufacturing sectors, and for the ICT-intensive service sector. For the variables important to the two chief hypotheses of this paper, namely the variables related to the application of HRM practices, it may be said overall, that these variables were found to affect innovation performance positively. For what concern individual practices, some effect was detected, in particular for what go for "team work" practices. However, when all of the HRM practices were combined into one single variable, the effect was found to be much stronger. Hence, this finding is consistent with hypothesis (i), since it may be concluded that complementarities between the various practices obtain. With regard to hypothesis (ii) (the 
"sectoral hypothesis"), it could indeed be concluded that firms in sectors with seemingly higher levels of knowledge-intensity in their production processes, get a higher outcome from engaging in the application of new HRM practices.

Theoretical analysis in the field of economic organisation has focussed almost exclusively on identifying organisational practices and complementarities between such practices, invariant to the type of activity in question (e.g., Milgrom and Roberts, 1995). The results of this paper are therefore informing, since they strongly suggest that this simplifying assumption is not reflected in reality. Therefore - at the theoretical level — there appears to be a need for an integration of contingency factors with the theory of organisational complementarity. Nevertheless, while this paper has brought us some way towards displaying the effect of HRM complementarities, it still remains limited in a number of ways. First, while the DISKO data set is rather detailed when it comes to variables measuring how work is organised ("job rotation", "interdisciplinary workgroups", etc.), the data set remains very limited when it comes to variables measuring incentives within firms (such as various remuneration schemes). The lack of such measures makes a more precise analysis, of from where the complementarity effects really stem, rather difficult. Second, while the HRM complementarity effect on innovation performance is interesting per se, it should be corroborated by analyses making use of other measures of performance, such as productivity and profit rates. 


\section{Appendix 1: The Sectoral Classification Applied in this Paper}

Pavitt (1984), identifies differences in the importance of different sources of innovation according to which broad sector the individual firm belongs. The taxonomy of firms, according to principal activity, emerged out of a statistical analysis of more than 2000 post-war innovations in Britain and was explained by the sources of technology; the nature of users needs; and means of appropriation. Four types of firms were identified accordingly, namely supplier dominated firms, scale-intensive firms, specialised suppliers and science-based firms. Supplier dominated firms are typically small. Most technology comes from suppliers of equipment and material. Scale-intensive firms are found in bulk materials and assembly. Their internal sources of technology are production engineering and R\&D departments. External sources of technology include mainly interactive learning with specialised suppliers, but also inputs from science-based firms are of some importance. Specialised suppliers are small firms, which are producers of production equipment and control instrumentation. Their main internal sources are primarily design and development. External sources are users (science-based and scale-intensive firms). Science based firms are found in the chemical and electronic sectors. Their main internal sources of technology are internal $R \& D$ and production engineering. Important external sources of technology include universities, but also specialised suppliers.

Since the Pavitt taxonomy was created mainly with the manufacturing sector in mind (although the crafts sector [see below] could be included in the supplier dominated sector, if one were to follow the original Pavitt taxonomy), and since we are conducting an analysis of firms in both manufacturing as well as in services, we have added five additional service sectors. ICT (Information and Communication Technology) intensive services are firms providing business services and financial services. Wholesale trade consists of firms selling bulk materials or machines. Scale-intensive services consists of typically large firms in the transport industries, cleaning service as well as of supermarkets and warehouses. Specialised services is made up of smaller firms including miscellaneous shops, hotels and restaurants, taxi companies etc. Crafts consists of firms in construction industries, as well as of automobile repair shops. For a detailed assignment of all industries into the nine sectors, see Appendix 2 to this paper. 


\section{Appendix 2: The Assignment of Industries Into Nine Sectoral Categories}

\begin{tabular}{|c|c|c|c|c|c|}
\hline No. & Industry & Sector & No. & Industry & Sector \\
\hline 1 & Production etc. of meat and meat products & SCAI & 43 & Sale of motor vehicles, motorcycles etc. & SSER \\
\hline 2 & Manufacture of dairy products & SCAI & 44 & Maintenance and repair of motor vehicles & CRAF \\
\hline 3 & Manufacture of other food products & SCAI & 45 & Service stations & SSER \\
\hline 4 & Manufacture of beverages & SCAI & 46 & Ws. of agricul. raw materials, live animals & WTRA \\
\hline 5 & Manufacture of tobacco products & SCAI & 47 & Ws. of food, beverages and tobacco & WTRA \\
\hline 6 & Manufacture of textiles and textile products & SDOM & 48 & Ws. of household goods & WTRA \\
\hline 7 & Mfr. of wearing apparel; dressing etc. of fur & SDOM & 49 & Ws. of wood and construction materials & WTRA \\
\hline 8 & Mfr. of leather and leather products & SDOM & 50 & Ws. of other raw mat. and semimanufactures & WTRA \\
\hline 9 & Mfr. of wood and wood products & SDOM & 51 & Ws. of machinery, equipment and supplies & WTRA \\
\hline 10 & Mfr. of pulp, paper and paper products & SDOM & 52 & Commission trade and other wholesale trade & WTRA \\
\hline 11 & Publishing of newspapers & SDOM & 53 & Re. sale of food in non-specialised stores & SCIS \\
\hline 12 & Publishing activities, excl. newspapers & SDOM & 54 & Re. sale of food in specialised stores & SSER \\
\hline 13 & Printing activities etc. & SDOM & 55 & Department stores & SCIS \\
\hline 14 & Mfr. of refined petroleum products etc. & SCAI & 56 & Retail sale of phar. goods, cosmetic art. etc. & SSER \\
\hline 15 & Mfr. of chemical raw materials & SCIB & 57 & Re. sale of clothing, footwear etc. & SSER \\
\hline 16 & Mfr. of paints, soap, cosmetics, etc. & SCAI & 58 & Re. sale of furniture, household appliances & SSER \\
\hline 17 & Mfr. of pharmaceuticals etc. & SCIB & 59 & Re. sale in other specialised stores & SSER \\
\hline 18 & Mfr. of plastics and synthetic rubber & SCAI & 60 & Repair of personal and household goods & SSER \\
\hline 19 & Mfr. of glass and ceramic goods etc. & SDOM & 61 & Hotels etc. & SSER \\
\hline 20 & Mfr. of cement, bricks, concrete ind. etc. & SCAI & 62 & Restaurants etc. & SSER \\
\hline 21 & Mfr. of basic metals & SCAI & 63 & Transport via railways and buses & SCIS \\
\hline 22 & Mfr. construction materials of metal etc. & SCAI & 64 & Taxi operation and coach services & SSER \\
\hline 23 & Mfr. of hand tools, metal packaging etc. & SDOM & 65 & Freight transport by road and via pipelines & SSER \\
\hline 24 & Mfr. of marine engines, compressors etc. & SPEC & 66 & Water transport & SCIS \\
\hline 25 & Mfr. of other general purpose machinery & SPEC & 67 & Air transport & SCIS \\
\hline 26 & Mfr. of agricultural and forestry machinery & SPEC & 68 & Cargo handling, harbours etc.; travel agencies & SCIS \\
\hline 27 & Mfr. of machinery for industries etc. & SPEC & 69 & Monetary intermediation & ITIS \\
\hline 28 & Mfr. of domestic appliances n.e.c. & SCAI & 70 & Other financial intermediation & ITIS \\
\hline 29 & Mfr. of office machinery and computers & $\mathrm{SCIB}$ & 71 & Insurance and pension funding & ITIS \\
\hline 30 & Mfr. of radio and communication equipment etc. & $\mathrm{SCIB}$ & 72 & Activities auxiliary to financial intermediates & ITIS \\
\hline 31 & Mfr. of medical and optical instruments etc. & SPEC & 73 & Letting of own property & SSER \\
\hline 32 & Building and repairing of ships and boats & SCAI & 74 & Real estate agents etc. & SSER \\
\hline 33 & Mfr. of transport equipment excl. ships, etc. & SCAI & 75 & Renting of machinery and equipment etc. & SSER \\
\hline 34 & Mfr. of furniture & SDOM & 76 & Computer and related activity & ITIS \\
\hline 35 & Mfr. of toys, gold and silver articles etc. & SDOM & 77 & Research and development & ITIS \\
\hline 36 & General contractors & CRAF & 78 & Legal activities & ITIS \\
\hline 37 & Bricklaying & CRAF & 79 & Accounting, book-keeping and auditing activities & ITIS \\
\hline 38 & Install. of electrical wiring and fittings & CRAF & 80 & Consulting engineers, architects etc. & ITIS \\
\hline 39 & Plumbing & CRAF & 81 & Advertising & ITIS \\
\hline 40 & Joinery installation & CRAF & 82 & Building-cleaning activities & SCIS \\
\hline 41 & Painting and glazing & CRAF & 83 & Other business services & ITIS \\
\hline 42 & Other construction works & CRAF & & & \\
\hline
\end{tabular}

SCAI = Scale-intensive firms; SDOM = Supplier dominated firms; SCIB = Science based firms; SPEC = Specialised suppliers; CRAF $=$ Crafts; WTRA $=$ Whole sale trade; SSER $=$ Specialised services $;$ SCIS $=$ Scaleintensive services; ITIS = ICT-intensive services. 


\section{References}

Aoki, M., 1990, Toward an economic model of the Japanese firm, Journal of Economic Literature 28, 1-27.

Aoki, M. and R. Dore, (Editors), 1994, The Japanese Firm: The Sources of Competitive Strength (Oxford University Press, Oxford).

Bolton, P. and J. Farrell, 1990, Decentralization, Duplication, and Delay, Journal of Political Economy 98, 803-826.

Burns, T. and G.M. Stalker, 1961, The Management of Innovation (Tavistock, London).

Cohen, S.G. and D.E. Bailey, 1995, What makes teams work? Group effectiveness research from the shop floor to the executive suite, Journal of Management 23, 239-290.

Geroski, P.A., 1990, Innovation, Technological Opportunity, and Market Structure, Oxford Economic Papers 42, 586-602.

Gjerding, A.N., (Editor), 1997, Den fleksible virksomhed: Omstillingspres og fornyelse i dansk erhvervsliv (Erhvervsudviklingsrådet, Copenhagen).

Grandori, A., 1987, Perspectives on Organization Theory (Ballinger Publishing Company, Cambridge, Massachusetts).

Greene, W.H., 1997, Econometric Analysis (Prentice-Hall, Upper Saddle River, New Jersey).

Hayek, F.A.v., 1948, The Use of Knowledge in Society, in: , Individualism and Economic Order (University of Chicago Press, Chicago).

Holmström, B., 1979, Moral Hazard and Observability, Bell Journal of Economics 10, 7491.

Holmström, B. and J. Roberts, 1998, The Boundaries of the Firm Revisited, Journal of Economic Perspectives 12, 73-94.

Huselid, M.A., 1995, The Impact of Human Resource Management Practices on Turnover, Productivity, and Corporate Financial Performance, Academy of Management Journal 38, 635-672.

Ichniowski, C., K. Shaw and G. Prennushi, 1997, The Effects of Human Resource Management Practices on Productivity: A Study of Steel Finishing Lines, American Economic Review 87, 291-313.

Itoh, H., 1993, Coalitions, Incentives, and Risk Sharing, Journal of Economic Theory 60, 410-427.

Itoh, H., 1994a, Co-ordination, Specialization, and Incentives in Product Development Organizations, in: M. Aoki and R. Dore (Editors), The Japanese Firm: The Sources of Competitive Strength (Oxford University Press, Oxford).

Itoh, H., 1994b, Japanese Human Resource Management from the Viewpoint of Incentive Theory, in: M. Aoki and R. Dore (Editors), The Japanese Firm: The Sources of Competitive Strength (Oxford University Press, Oxford).

Jensen, M.C. and W.H. Meckling, 1992, Specific and General Knowledge and Organizational Structure, in: L. Werin and H. Wijkander (Editors), Contract Economics (Blackwell, Oxford).

Kleinknecht, A., (Editor), 1996, Determinants of Innovation: The Message from New Indicators (Macmillan Press Ltd, London).

Kline, S. and N. Rosenberg, 1986, An Overview of Innovation, in: R. Landau and N. Rosenberg (Editors), The Positive Sum Strategy: Harnessing Technology for Economic Growth (National Academy Press, Washington, D.C.). 
Laursen, K. and N. Foss, 2000, New HRM Practices, Complementarities, and the Impact on Innovation Performance, IVS Working Paper no. 05 (Copenhagen Business School, Copenhagen).

Lawler, E.E.I., S.A. Mohrman and G.E. Ledford Jr., 1995, Creating high performance organizations: practices and results of employee involvement and total quality management in Fortune 1000 companies (Jossey-Bass, San Francisco).

Lawrence, P.R., 1981, Organization and Environment Perspective, in: V.d. Ven and W.F. Joyce (Editors), Perspectives on Organization Design and Behaviour (Wiley-Interscience, New York).

Malerba, F., 1992, Learning by Firms and Incremental Technical Change, Economic Journal $102,845-859$.

Mendelson, H. and R.R. Pillai, 1999, Information Age Organizations, Dynamics, and Performance, Journal of Economic Behavior and Organization 38, 253-281.

Michie, J. and M. Sheehan, 1999, HRM Practices, R\&D Expenditure and Innovative Investment: Evidence from the UK's 1990 Workplace Industrial Relations Survey, Industrial and Corporate Change 8, 211-234.

Milgrom, P. and J. Roberts, 1990, The Economics of Modern Manufacturing Technology, Strategy and Organization, American Economic Review 80, 511-528.

Milgrom, P. and J. Roberts, 1995, Complementarities and fit: Strategy, structure, and organizational change in manufacturing, Journal of Accounting and Economics 19, 179208.

Ouchi, W.G., 1979, A Conceptual Framework for the Design of Organizational Control Mechanisms, Management Science 25, 833-848.

Ouchi, W.G., 1980, Markets, Bureaucracies, and Clans, Administrative Science Quarterly 25, 129-141.

Pavitt, K.L.R., 1984, Sectoral Patterns of Technical Change: Towards a Taxonomy and a Theory, Research Policy 13, 343-373.

Penrose, E.T., 1959, The Theory of the Growth of the Firm (Basil Blackwell, Oxford).

Prendergast, C., 1999, The Provision of Incentives in Firms, Journal of Economic Literature 37, 7-63.

Prendergast, C., 2000, The Tenuous Tradeoff Between Risk and Incentives, NBER Working Paper 7815,

Rothwell, R., C. Freeman, P. Jervis, A. Robertson and J. Townsend, 1974, SAPPHO Updated -Project SAPPHO Phase 2., Research Policy 3, 258-291.

Schumpeter, J.A., 1912/1934, The Theory of Economic Development: An Inquiry into Profits, Capital, Credit, Interest and the Business Cycle (Oxford University Press, London).

von Hippel, E., 1988, The Sources of Innovation (Oxford University Press, New York and Oxford).

Zenger, T. and W.S. Hesterly, 1997, The Disaggregation of Corporations: Selective Intervention, High-Powered Incentives and Molecular Units, Organization Science 8, 209-222. 


\title{
$D_{\text {anish }} \mathbf{R}_{\text {esearch }} \mathbf{U}_{\text {nit for }} \mathbf{I}_{\text {ndustrial }} \mathbf{D}_{\text {ynamics }}$
}

\author{
The Research Programme
}

The DRUID-research programme is organised in 3 different research themes:

\section{- The firm as a learning organisation}

- Competence building and inter-firm dynamics

- The learning economy and the competitiveness of systems of innovation

In each of the three areas there is one strategic theoretical and one central empirical and policy oriented orientation.

\section{Theme A: The firm as a learning organisation}

The theoretical perspective confronts and combines the resource-based view (Penrose, 1959) with recent approaches where the focus is on learning and the dynamic capabilities of the firm (Dosi, Teece and Winter, 1992). The aim of this theoretical work is to develop an analytical understanding of the firm as a learning organisation.

The empirical and policy issues relate to the nexus technology, productivity, organisational change and human resources. More insight in the dynamic interplay between these factors at the level of the firm is crucial to understand international differences in performance at the macro level in terms of economic growth and employment.

\section{Theme B: Competence building and inter-firm dynamics}

The theoretical perspective relates to the dynamics of the inter-firm division of labour and the formation of network relationships between firms. An attempt will be made to develop evolutionary models with Schumpeterian innovations as the motor driving a Marshallian evolution of the division of labour.

The empirical and policy issues relate the formation of knowledge-intensive regional and sectoral networks of firms to competitiveness and structural change. Data on the structure of production will be combined with indicators of knowledge and learning. IO-matrixes which include flows of knowledge and new technologies will be developed and supplemented by data from case-studies and questionnaires. 
Theme C: The learning economy and the competitiveness of systems of innovation.

The third theme aims at a stronger conceptual and theoretical base for new concepts such as 'systems of innovation' and 'the learning economy' and to link these concepts to the ecological dimension. The focus is on the interaction between institutional and technical change in a specified geographical space. An attempt will be made to synthesise theories of economic development emphasising the role of science basedsectors with those emphasising learning-by-producing and the growing knowledgeintensity of all economic activities.

The main empirical and policy issues are related to changes in the local dimensions of innovation and learning. What remains of the relative autonomy of national systems of innovation? Is there a tendency towards convergence or divergence in the specialisation in trade, production, innovation and in the knowledge base itself when we compare regions and nations?

\section{The Ph.D.-programme}

There are at present more than 10 Ph.D.-students working in close connection to the DRUID research programme. DRUID organises regularly specific Ph.D-activities such as workshops, seminars and courses, often in a co-operation with other Danish or international institutes. Also important is the role of DRUID as an environment which stimulates the Ph.D.-students to become creative and effective. This involves several elements:

- access to the international network in the form of visiting fellows and visits at the sister institutions

- participation in research projects

- access to supervision of theses

- access to databases

Each year DRUID welcomes a limited number of foreign Ph.D.-students who wants to work on subjects and project close to the core of the DRUID-research programme.

\section{External projects}

DRUID-members are involved in projects with external support. One major project which covers several of the elements of the research programme is DISKO; a comparative analysis of the Danish Innovation System; and there are several projects involving international co-operation within EU's 4th Framework Programme. DRUID is open to host other projects as far as they fall within its research profile. Special attention is given to the communication of research results from such projects to a wide set of social actors and policy makers. 


\section{DRUID Working Papers}

96-1 Lundvall, Bengt-Åke: The Social Dimension of the Learning Economy. (ISBN 87-7873-000-7)

96-2 Foss, Nicolai J.: Firms, Incomplete Contracts and Organizational Learning. (ISBN 87-7873-001-5)

96-3 Dalum, Bent and Villumsen, Gert: Are OECD Export Specialisation Patterns Sticky?' Relations to the Convergence-Divergence Debate. (ISBN 87-7873-002-3)

96-4 Foss, Nicolai J: Austrian and Post-Marshallian Economics: The Bridging Work of George Richardson. (ISBN 87-7873-003-1)

96-5 Andersen, Esben S., Jensen, Anne K., Madsen, Lars and Jørgensen, Martin: The Nelson and Winter Models Revisited: Prototypes for ComputerBased Reconstruction of Schumpeterian Competition. (ISBN 87-7873-005-8)

96-6 Maskell, Peter: Learning in the village economy of Denmark. The role of institutions and policy in sustaining competitiveness. (ISBN 87-7873-006-6)

96-7 Foss, Nicolai J. \& Christensen, Jens Frøslev: A Process Approach to Corporate Coherence. (ISBN 87-7873-007-4)

96-8 Foss, Nicolai J.: Capabilities and the Theory of the Firm. (ISBN 87-7873008-2)

96-9 Foss, Kirsten: A transaction cost perspective on the influence of standards on product development: Examples from the fruit and vegetable market. (ISBN 87-7873-009-0)

96-10 Richardson, George B.: Competition, Innovation and Increasing Returns. (ISBN 87-7873-010-4)

96-11 Maskell, Peter: Localised low-tech learning in the furniture industry. (ISBN 87-7873-011-2)

96-12 Laursen, Keld: The Impact of Technological Opportunity on the Dynamics of Trade Performance. (ISBN 87-7873-012-0) 
96-13 Andersen, Esben S.: The Evolution of an Industrial Sector with a Varying Degree of Roundaboutness of Production. (ISBN 87-7873-013-9)

96-14 Dalum, Bent, Laursen, Keld \& Villumsen, Gert: The Long Term Development of OECD Export Specialisation Patterns: De-specialisation and "Stickiness". (ISBN 87-7873-014-7)

96-15 Foss, Nicolai J.: Thorstein B. Veblen: Precursor of the Competence-Based Approach to the Firm. (ISBN 87-7873-015-5)

96-16 Gjerding, Allan Næs: Organisational innovation in the Danish private business sector. (ISBN 87-7873-016-3)

96-17 Lund, Reinhard \& Gjerding, Allan Næs: The flexible company Innovation, work organisation and human ressource management. (ISBN 87-7873-017-1)

97-1 Foss, Nicolai J.: The Resource-Based Perspective: An Assessment and Diagnosis of Problems. (ISBN 87-7873-019-8)

97-2 Langlois, Richard N. \& Foss, Nicolai J.: Capabilities and Governance: the Rebirth of Production in the Theory of Economic Organization. (ISBN 877873-020-1)

97-3 Ernst, Dieter: Partners for the China Circle? The Asian Production Networks of Japanese Electronics Firms. (ISBN 87-7873-022-8)

97-4 Richardson, George B.: Economic Analysis, Public Policy and the Software Industry. (ISBN 87-7873-023-6)

97-5 Borrus, Michael \& Zysman, John: You Don't Have to Be A Giant: How The Changing Terms of Competition in Global Markets are Creating New Possibilities For Danish Companies. (ISBN 87-7873-024-4)

97-6 Teubal, Morris.: Restructuring and Embeddeness of Business EnterprisesTowards an Innovation System Perspective on Diffusion Policy. (ISBN 877873-025-2)

97-7 Ernst, Dieter \& Guerrieri, Paolo: International Production Networks and Changing Trade Patterns in East Asia: The case of the Electronics Industry. (ISBN 87-7873-026-0)

97-8 Lazaric, Nathalie \& Marengo, Luigi: Towards a Characterisation of Assets and Knowledge Created in Technological Agreements: Some evidence from the automobile-robotics sector. (ISBN 87-7873-027-9) 
97-9 Ernst, Dieter.: High-Tech Competition Puzzles. How Globalization Affects Firm Behavior and Market Structure in the Electronics Industry. (ISBN 877873-028-7)

97-10 Foss, Nicolai J.: Equilibrium vs Evolution in the Resource-Based Perspective: The Conflicting Legacies of Demsetz and Penrose. (ISBN 877873-029-5)

97-11 Foss, Nicolai J.: Incomplete Contracts and Economic Organisation: Brian Loasby and the Theory of the firm. (ISBN 87-7873-030-9)

97-12 Ernst, Dieter \& Lundvall, Bengt-Åke: Information Technology in The Learning Economy - Challenges for Developing Countries. (ISBN 87-7873031-7)

97-13 Kristensen, Frank Skov (p): A study of four organisations in different competitive environments. (ISBN 87-7873-032-5)

97-14 Drejer, Ina, (p) Kristensen, Frank Skov (p) \& Laursen, Keld (p): Studies of Clusters as a Basis for Industrial and Technology Policy in the Danish Economy. (ISBN 87-7873-033-3)

97-15 Laursen, Keld (p) \& Drejer, Ina (p): Do Inter-sectoral Linkages Matter for International Export Specialisation? (ISBN 87-7873-034-1)

97-16 Lundvall, Bengt-Åke \& Kristensen, Frank Skov (p): Organisational change, innovation and human resource Development as a response to increased competition. (ISBN 87-7873-036-8)

98-1 Præst, Mette (p): An Empirical Model of Firm Behaviour: A dynamic Approach to Competence Accumulation and Strategic Behaviour. (ISBN 877873-037-6)

98-2 Ducatel, Ken: Learning and skills in the Knowledge Economy. (ISBN 877873-038-4)

98-3 Ernst, Dieter: What Permits Small Firms to Compete in High-Tech Industries? Inter-Organizational Knowledge Creation in the Taiwanese Computer Industry. (ISBN 87-7873-039-2)

98-4 Christensen, Jens Frøslev: The Dynamics of the Diversified Corporation and the Role of Central Management of Technology. (ISBN 87-7873-040-6)

98-5 Valente, Marco (p): Laboratory for Simulation Development. (ISBN 877873-041-4)

98-6 Valente, Marco (p): Technological Competition: a Qualitative Product Life 
Cycle. (ISBN 87-7873-042-2)

98-7 Lam, Alice: The Social Embeddedness of Knowledege: Problems of Knowledge Sharing and Organisational Learning in International HighTechnology Ventures. (ISBN 87-7873-043-0)

98-8 Jørgensen, Kenneth M. (p): Information Technology and Change in Danish Organizations. (ISBN 87-7873-044-9)

98-9 Andersen, Esben Sloth: Escaping Satiation in an Evolutionary Model of Structural economic Dynamics. (ISBN 87-7873-045-7)

98-10 Foss, Kirsten: Technological Interdependencies, Specialization and Coordination: A Property Rights Perspective on The Nature of the Firm. (ISBN 87-7873-046-5)

98-11 Andersen, Poul H: Organizing International Technological Collaboration in Subcontractor Relationships. An Investigation of the Knowledge-Stickyness Problem. (ISBN 87-7873-047-3)

98-12 Nymark, Søren (p): Billeder af strategi i forandringsrige organisatoriske omgivelser: 3 cases fra DISKO studierne. (ISBN 87-7873-048-1)

98-13 Andersen, Esben Sloth: The Evolution of the Organisation of Industry. (ISBN 87-7873-050-3)

98-14 Foss, Kirsten \& Foss, Nicolai J.: The Market Process and The Firm: Toward a Dynamic Property Rights Perspective. (ISBN 87-7873-051-1)

98-15 Lorenz, Edward: Societal Effects and the Transfer of Business Practices to Britain and France. (ISBN 87-7873-053-8)

98-16 Ernst, Dieter: Catching-Up, Crisis and Industrial Upgrading. Evolutionary Aspects of Technological Learning in Korea's Electronics Industry. (ISBN 87-7873-054-6)

98-17 Kaisla, Jukka (p): The Market Process and the Emergence of the Firm: Some Indications of Entrepreneurship Under Genuine Uncertainty. (ISBN 87-7873-055-4)

98-18 Laursen, Keld (p): Do Export and Technological Specialisation Patterns Co-evolve in Terms of Convergence or Divergence?: Evidence from 19 OECD Countries, 1971-1991. (ISBN 87-7873-056-2)

98-19 Foss, Nicolai J.: Firms and the Coordination of Knowledge: Some Austrian Insights. (ISBN 87-7873-057-0)

98-20 Mahnke, Volker (p) \& Aadne, John Harald: Process of Strategic Renewal, Competencies, and the Management of Speed. (ISBN 87-7873-058-9) 
98-21 Lorenzen, Mark (p): Information, cost learning, and trust. Lessons form cooperation and higher-order capabilities amongst geographically proximate firms. (ISBN 87-7873-059-7)

98-22 Lam, Alice: Tacit Knowledge, Organisational Learning and Innovation: A Societal Perspective. (ISBN 87-7873-060-0)

98-23 Lund, Reinhard: Organizational and innovative flexibility mechanisms and their impact upon organizational effectiveness. (ISBN 87-7873-061-9)

98-24 Christensen, Jesper Lindgaard \& Drejer, Ina (p): Finance and Innovation System or Chaos. (ISBN 87-7873-062-7)

98-25 Laursen, Keld (p): How Structural Change Differs, and Why it Matters (for Economic Growth) (ISBN 87-7873-063-5)

98-26 Holmén, Magnus \& Jacobsson, Staffan: A method for identifying actors in a knowledge based cluser. (ISBN 87-7873-064-3)

98-27 Richardson, G. B.: Production, Planning and Prices. (ISBN 87-7873-065-1)

98-28 Foss, Nicolai J.: Austrian Economics and Game Theory: a Preliminary Methodological Stocktaking. (ISBN 87-7873-067-8)

98-29 Foss, Nicolai J. \& Mahnke, Volker (p): Strategy Research and the Market Process Perspective. (ISBN 87-7873-068-6)

98-30 Laursen, Keld (p): Revealed Comparative Advantage and the Alternatives as Measures of International Specialisation. (ISBN 87-7873-069-4)

99-1 Lorenz, E.: Organisationaal Innovation, Governance Structure and Innovative Capacity In British and French Industry. (ISBN 87-7873-070-8)

99-2 Ernst, Dieter: Responses to the Crisis: Constraints to a Rapid Trade Adjustment in East Asia's Electronics Industry. (ISBN 87-7873-071-6)

99-3 Foss, N. J. : Understanding Leadership: A Coordination Theory. (ISBN 877873-072-4)

99-4 Foss, K \& Foss, N. J: Understanding Ownership: Residual Rights of Control and Appropriable Control Rights. ( ISBN 87-7873-073-2)

99-5 Foss, K \& Foss, N. J: Organizing Economic Experiments: The role of Firms. (ISBN 87-7873-075-9)

99-6 Jørgensen Kenneth. M. (p) : The Meaning og Local Knowledges. (ISBN 87-7873-076-7)

99-7 Foss, N. J.: Capabilities, Confusion, and the Costs of Coordination: On Some Problems in Recent Research On Inter-Firm Relations. (ISBN87-7873- 
077-5)

99-8 Lund, Reinhard: Tillidsrepræsentantsystemet og de

fleksiblevirksomhedsformer. Juli 1999. (ISBN887-7873-078-3)

99-9 Nymark, Søren: Organisatorisk læring gennem den værdibaserede organisations fortællinger. (ISBN 87-7873-079-1)

99-10 Laursen, K. \& Meliciani, V.: The importance of technology based intersectoral linkages for market share dynamics. (ISBN 87-7873-080-5)

99-11 Laursen, K., Mahnke, V., Vejrup-Hansen, P.: Firm growth from a knowlegde structure perspective. ( ISBN 87-7873-081-3)

99-12 Lundvall, Bengt-Åke, Christensen, Jesper. L.: Extending and Deepening the Analysis of Innovation Systems - with Emperical Illustrations from the DISCO-project. (ISBN 87-7873-082-1)

00-1 Llerena, Patrick \& Oltra, Vanessa: Diversity of innovative strategy as a source technological performance. (ISBN 87-7873-085-6)

00-2 Llerena, Patrick \& Mireille Matt: Technology policy and cooperation: A paradigmatic approach. (ISBN 87-7873-086-4)

00-3 Cusmano, Lucia: Technology Policy and Co-operative R\&D: the role of relational research capacity. (ISBN 87-7873-087-2)

00-4 Mikkola, Juliana Hsuan: Modularization assessment of product architecture. (ISBN87-7873-088-0)

00-5 Yvrande, Anne: The new British railways structure: A transaction cost economics analysis. (ISBN87-7873-089-9)

00-6 Dijk, Machiel van \&Nomaler Önder: Technological diffusion patterns and their effects on industrial dynamics. (ISBN 87-7873-090-2)

00-7 Storper, Michael \& Chen, Yun-chung with De Paolis, Fernando: The Effects of Globalization on Location of Industries in the OECD and European Union (ISBN87-7873-091-0)

00-8 Sanders, Mark \& Weel, Bas ter : Skill-Biased Technical Change: Theoretical Concepts, Empirical Problems and a Survey of the Evidence (ISBN87-7873-092-9)

00-9 Tomlinson, Mark: Innovation surveys: A researcher's perspective (ISBN87-7873-093-7)

00-10 Nymark, Søren: Value-based management in learning organizations through 'hard' and 'soft' managerial approaches: The case of Hewlett-Packard 
(ISBN87-7873-094-5)

00-11 Yoguel, Gabriel; Novick, Marta \& Marin, Anabel: Production Networks: Linkages, Innovation Processes and Social Management Technologies (ISBN87-7873-095-3)

00-12 Yoguel, Gabriel \& Boscherini, Fabio: The environment in the development of firms' innovative capacities: Argentine industrial SMEs from different local systems (ISBN87-7873-096-1)

00-13 Arocena, Rodrigo \& Sutz, Judith: Interactive Learning Spaces and Development Policies in Latin America (ISBN87-7873-098-8)

01-01 Mathews, John A.: Competitive Interfirm Dynamics within an Industrial Market System ( ISBN87-7873-099-6)

01-02 Giarratana, Marco \& Torrisi, Salvatore: Competence accumulation and collaborative ventures: Evidence from the largest European electronics firms and implications for the EU technological policies (ISBN 87-7873-100-3)

01-03 Nemirovsky, Adolfo \& Yoguel, Gabriel: Dynamics of high-technology firms in the Silicon Valley (ISBN 87-7873-101-1)

01-04 Castellacci, Fulvio: A 'technology-gap approach to cumulative growth': toward an integrated model. Empirical evidence for Spain, 1960-1997 (ISBN 87-7873-103-8)

01-05 Nuvolari. Alessandro: Collective invention during the British industrial revolution: The case of the Cornish pumping engine (ISBN 87-7873-104-6)

01-06 Costa, Ionara: Ownership and technological capabilities in Brazil (ISBN 877873-105-4)

01-07 Foss, Nicolai J.: Economic organization in the knowledge economy: some austrian insights (ISBN 87-7873-106-2)

01-08 Cantwell, John \& Kosmopoulou, Elena: Determinants of internationalisation on corporate technology (ISBN 87-7873-107-0)

01-09 Loasby, Brian: Industrial dynamics. Why connection matter (ISBN 87-7873108-9)

01-10 Jeppesen, Lars Bo: Making Consumer Knowledge Available and useful (877873-109-7)

01-11 Laursen, Keld: The Importance of Sectoral Differences in the Application of (Complementary) HRM Practices for Innovation Performance (87-7873$110-0)$ 
All correspondence concerning the DRUID Working Papers should be send to:

\section{Jonna Jacobsen}

Fibigerstræde 4 DK-9220 Aalborg OE

Tel. 4596358265

Fax. 4598156013

E-mail: druid-wp@business.auc.dk 